\title{
Cytomegalovirus pneumonitis in an HIV positive patient
}

\author{
T.D.R.N Perera ${ }^{1}$, Ariyaratne K. A. Manathunge ${ }^{2}$, K. Thirumavalavan ${ }^{3}$
}

\begin{abstract}
A 64-year-old newly diagnosed retroviral positive, unmarried male with a CD4 count of 77 cells $/ \mathrm{mm}^{3}$ presented with productive cough, fever, wheezing and pleuritic type chest pain for 5 days duration. On examination he had $\mathrm{B} / \mathrm{L}$ rhonchi and crepitations. His baseline investigations and CXR were normal. Pneumocystis jirovecii pneumonia prophylaxis, isoniazid prophylaxis and antiretroviral treatment (ART) was started. Within first week of starting ART, his respiratory symptoms got worsened. Repeat investigations had no significance other than the rising CMV quantitative DNA PCR from $2290 \mathrm{IU} / \mathrm{ml}$ to $2.03 \times 10^{4} \mathrm{IU} /$ $\mathrm{ml}$. Repeat CXR revealed right side pleural effusion with underling collapse and consolidation. HRCT was compatible with CMV pneumonitis. Mild pericardial effusion was seen in the 2D ECHO. Patient improved with intravenous Ganciclovir. Here, we present a possible case of CMV pneumonitis, as it should be considered in the differential diagnosis of patients with rising CMV quantitative DNA PCR even with a higher CD4 count.
\end{abstract}

Keywords: CMV Pneumonitis, CMV quantitative DNA PCR, HIV, high CD4 count

Authors: ${ }^{1}$ Dr T.D.R.N Perera (MBBS, PgD Ven), Registrar in Venereology, National STD/AIDS Control Programme, Sri Lanka., ${ }^{2}$ Dr Ariyaratne K. A. Manathunge, (MBBS, MD); Consultant Venereologist, National STD/AIDS Control Programme, Sri Lanka. E mail: ariyaratne1@gmail.com, ${ }^{3} \mathrm{Dr}$ K Thirumavalavan, (MD, MRCP,FRCPE/MBBS, FACP FCCP, DFM, DIRNEPH), Consultant Physician, National Hospital, Sri Lanka.

Corresponding author: ${ }^{1}$ Dr T.D.R.N Perera, Email; rachiniperera81@gmail.com, https://orcid.org/0000-0002-1697-3355

Copyright

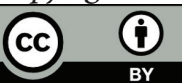

Acknowledgement: National Hospital of Sri Lanka, Word 50 staff

Conflict of interest: No conflict of interest

Funding: No funding support

Originality: This is an original work and no previous publications, presented at 23rd Annual Scientific Sessions of Sri Lanka College of Sexual Health and HIV Medicine 2018.

Submitted on: 15.10.201; Accepted on: 24.11.2018 


\section{Case Report}

Introduction

Cytomegalovirus (CMV) pneumonitis is extremely uncommon.(1) It has high mortality. Extent of disease ranged from minimal interstitial pneumonitis to sever diffuse alveolar damage.(1) Definitive diagnosis is by demonstrating inclusion bodies in lung tissue or cytology. End organ disease occurs typically with CD 4 counts $<50$ cells/mm3.(1) There are few reported cases of CMV pneumonitis in patients with high CD4 counts in the world. Literature survey didn't reveal any reported cases from Sri Lanka.

\section{Case history}

A 64 years old, unmarried, manual worker from Colombo was treated for seborrheic dermatitis at skin clinic NHSL and found to be retroviral positive. When he was referred to National STD/ AIDS control programme he had productive cough with whitish sputum and fever for five days duration, together with wheezing and pleuritic type chest pain. No hemoptysis. He was a smoker. No other comorbidities. He has had an unprotected sexual exposure with a female sex worker about seven years ago and that was his first and last sexual contact. On examination he was not pale, afebrile, anicteric, had oral candidiasis, slightly dyspneic, had sinus tachycardia and $\mathrm{SpO} 2$ was 98\%. There were no clubbing or lymphadenopathy. He also had B/L crepitations and rhonchi, but no hepatosplenomegaly. $\mathrm{He}$ had no neurological sings.

Patient was started with pneumocystis jirovecii pneumonia (PJP) prophylaxis, isoniazid (INAH) prophylaxis for latent tuberculosis. Highly active antiretroviral therapy (ART) was started comprising Tenofovir (TDF), Emtricitabine (FTC) and Lopinavir/ritonavir (LPV/r) as he was in a depressed mood. Within first week of starting ART his respiratory symptoms worsened. Breath sounds of the right lung was reduced, but the oxygen saturation was maintained. Repeat investigations had no significance other than the rising CMV quantitative DNA PCR from $2290 \mathrm{IU} / \mathrm{ml}$ to $2.03 \times 10^{4}$ $\mathrm{IU} / \mathrm{ml}$. Repeat CXR revealed right sided pleural effusion. Ultrasound chest: $\mathrm{B} / \mathrm{L}$ minimal pleural effusion with underling collapse and consolidation, left more than right. Maximum thickness less than $1 \mathrm{~cm}$ and it was difficult to aspirate. The 2D ECHO revealed a mild pericardial effusion with $\mathrm{EF}$ of $60 \%$. HRCT gave a differential diagnosis of CMV pneumonitis and acute interstitial pneumonia.
Table 1. Baseline investigations

\begin{tabular}{|c|c|}
\hline Test & Result \\
\hline CD4 & 77 cells/mm3 \\
\hline CD4/CD8 & 0.006 \\
\hline VL( Base line) & 1986180 copies/ml \\
\hline VDRL/TPPA & None reactive/negative \\
\hline HBS Ag/ HCV Ab & Negative \\
\hline FBC & Thrombocytopenia \\
\hline Blood picture & Viral pathology \\
\hline Sputum culture & No growth \\
\hline Blood pyogenic culture & No growth \\
\hline Sputum AFB & Negative \\
\hline Sputum Gene X pert & Negative \\
\hline Tuberculosis(TB) culture & No growth \\
\hline Atypical mycobacterium culture & No growth \\
\hline Monteux & $5 \mathrm{~mm}$ \\
\hline ESR & $80 \mathrm{mmhg} / 1 \mathrm{st} \mathrm{h}$ \\
\hline CXR & Normal \\
\hline CRP & $55 \mathrm{mg} / \mathrm{dl}$ \\
\hline Blood fungal Cultures & No growth \\
\hline RFT & Normal \\
\hline AST & $122 \mathrm{ul}$ \\
\hline ALT & $68 \mathrm{ul}$ \\
\hline ALP & 89 ul \\
\hline Serum bilirubin & Normal \\
\hline Albumin/globulin & $35 / 53$ \\
\hline USS abdomen & Normal \\
\hline Toxoplasma IgG Ab & Negative \\
\hline Sputum PJP stain & Negative \\
\hline Serum Cryptococcus Ag & Negative \\
\hline CMV IgM, IgG & Positive \\
\hline CMV PCR (base line) & $2290 \mathrm{IU} / \mathrm{ml}$ \\
\hline CMV retinitis & Excluded \\
\hline
\end{tabular}

Thrombocytopenia was persisting but there was no other evidence of CMV disease like myelopathy/ radiculopathy and gastrointestinal symptoms in this patient.

He was treated with intravenous Ganciclovir $250 \mathrm{mg}$ twice daily for six weeks. After ten days of treatment CMV quantitative DNA PCR was reduced to $1.33 \times 104 \mathrm{IU} / \mathrm{L}$ and after completion of treatment 
Figure 1 HRCT-Showing differential diagnosis of CMV pneumonitis and acute interstitial pneumonia.

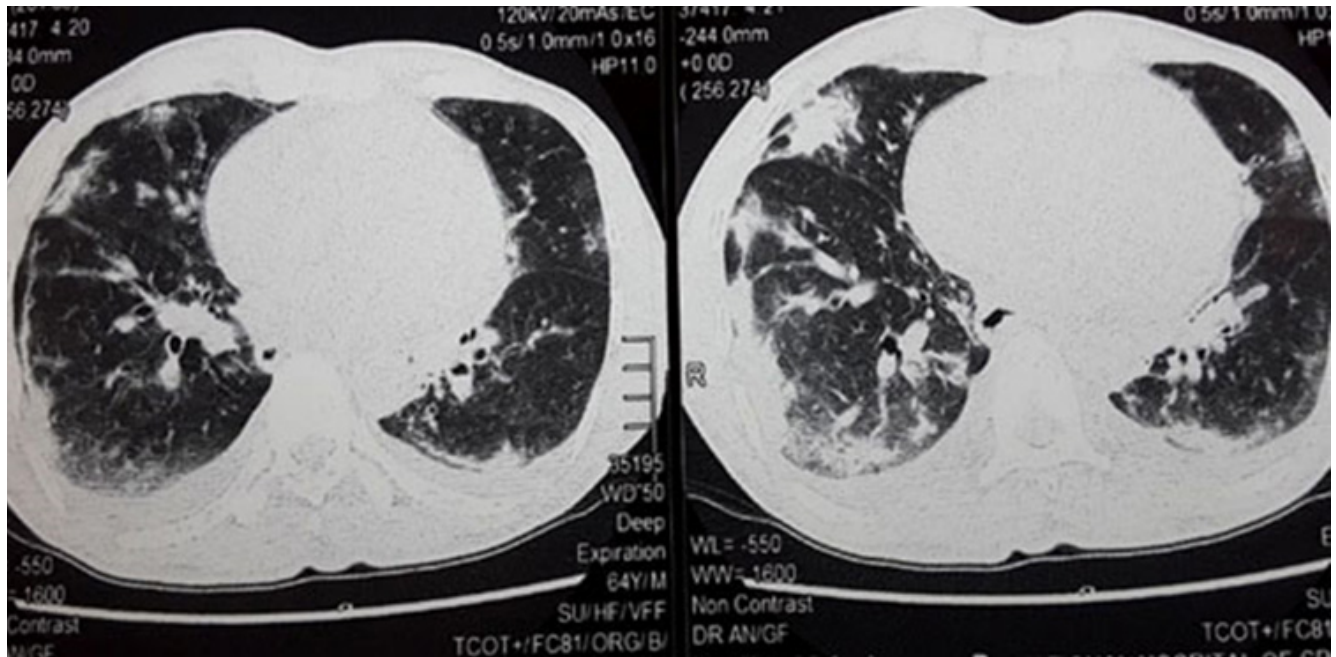

CMV quantitative DNA PCR was undetectable. Patients' symptoms and radiological abnormalities resolved completely.

Figure 2-CXR showing B/L pleural effusion with underling consolidation

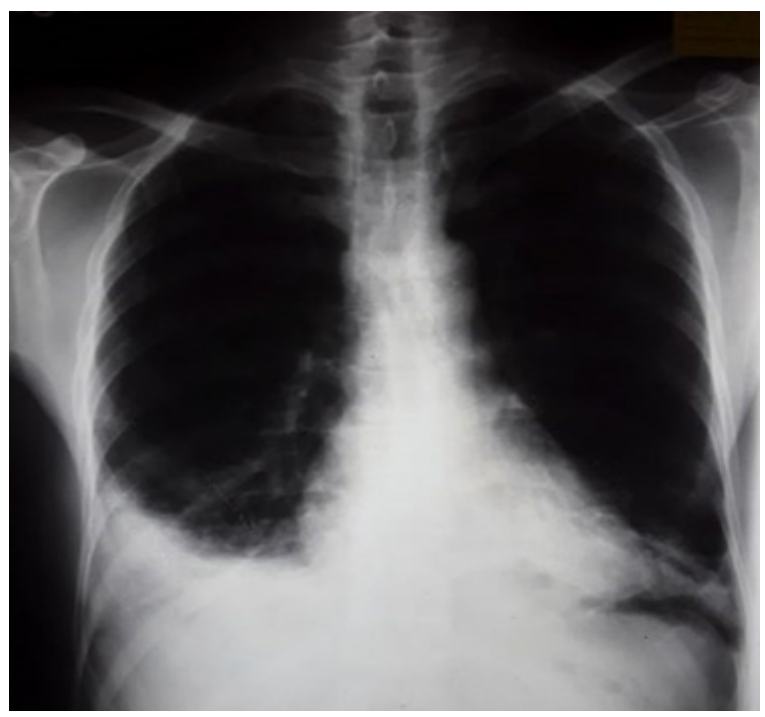

Discussion

This patient was managed as CMV pneumonitis based on clinical grounds supported by rising CMV quantitative DNA PCR, compatible HRCT findings with normal other baseline investigations and cultures. His HRCT finding suggested peripheral, basal air space consolidation involving both lungs, ground glass areas surrounding the consolidation, peri bronchovascular consolidations and $\mathrm{B} / \mathrm{L}$ mild pleural effusion with a differential diagnosis of acute interstitial pneumonia. Although not specific Georgeann study on CT findings also gives evidence of ground glass attenuation, consolidations, pleural effusions, reticular infiltrates which begin at the periphery of lower lobes and spreads centrally and also pulmonary nodules or masses to suspect CMV Pneumonitis.(2) In this study, almost all patients had CD 4 counts below 50 cells $/ \mathrm{mm}^{3}(2)$ in which our patient had relatively high CD4 count. Some studies concluded that it is likely to occur with CD4 counts up to 200 cells $/ \mathrm{mm}^{3}$. (3) Some studies concluded that CMV viraemia with CMV quantitative DNA PCR $>500$ copies/ml predict increased mortality despite ART initiation. Univariate analysis show CMV quantitative DNA PCR has a significant predictive value for the development of CMV disease.(4)

\section{Conclusion}

Although rare, if clinically suggestive, CMV pneumonitis should be considered as a differential diagnosis in patients with rising CMV quantitative DNA PCR even with a higher CD4 count.

\section{References}

1. CDC. Guidelines for the Prevention and Treatment of Opportunistic Infections in HIV-Infected Adults. 2016;N1-11. Available from: http://aidsinfo.nih. gov/ guidelines.

2. Georgeann $M$, Leitman S, Garay $M$, Naidich P. Cytomegalovirus Pneumonitis: Spectrum of Parenchymal CT Findings with Correlation Pneumonitis: in 21 AIDS Patients. Thorac Radiol. 1994;451-9.

3. Masur H. CD4 Counts as Predictors of Opportunistic Pneumonias in Human Immunodeficiency Virus (HIV) Infection. Ann Intern Med [Internet]. 1989;111(3):223. Available from: http://annals.org/ article.aspx. doi $=10.7326 / 0003-4819-111-3-223$

4. Dodt KK, Jacobsen PH, Hofmann B, Meyer C, Kolmos HJ, Skinhoj P, et al. Development of CMV disease may be predicted in HIV infected patients by CMV PCR and the antigenemia test. Raoid Sci Publ. 1997;11, No 3(November 1996):A-107-A-107. 